Int. J. Electrochem. Sci., 15 (2020) 12103 - 12121

International Journal of

ELECTROCHEMICAL

SCIENCE

www.electrochemsci.org

\title{
Effect of SiC Concentration on Microstructure and Properties of Ni-Co/SiC Nanocomposites Fabricated by Pulse Electrodeposition
}

\author{
Tianxiang Liu ${ }^{1 *}$, Chunyang $\mathrm{Ma}^{2,{ }^{*}}$, Qiang $\mathrm{Li}^{2}$, Jun $\mathrm{Li}^{3}$, Fafeng Xia ${ }^{2}$, Chaoyu $\mathrm{Li}^{2}$ \\ ${ }^{1}$ College of Engineering, Heilongjiang Bayi Agricultural University, Daqing 163319, China; \\ ${ }^{2}$ College of Mechanical Science and Engineering, Northeast Petroleum University, Daqing 163318, \\ China; \\ ${ }^{3}$ State Grid Integrated Energy Service Group Co. LTD, Beijing 100052, China \\ "E-mail: chunyangandma1@163.com
}

doi: $10.20964 / 2020.12 .25$

Received: 1 August 2020 / Accepted: 12 September 2020 / Published: 31 October 2020

In this article, $\mathrm{Ni}-\mathrm{Co} / \mathrm{SiC}$ nanocomposites were successfully deposited by pulse current electrodeposition using modified nickel and cobalt acid solution containing $\mathrm{SiC}$ nanoparticles. Effects of $\mathrm{SiC}$ concentration on microstructure, microhardness, and properties of $\mathrm{Ni}-\mathrm{Co} / \mathrm{SiC}$ nanocomposites were analyzed by transmission electron microscopy (TEM), scanning electron microscopy (SEM), Xray diffraction (XRD), microhardness tests, atomic force microscopy (AFM), and electrochemical tests. The results demonstrated that $\mathrm{SiC}$ content in $\mathrm{Ni}-\mathrm{Co} / \mathrm{SiC}$ nanocomposites increased to $9.0 \mathrm{wt} \%$ when $\mathrm{SiC}$ concentration increased from 0 to $10 \mathrm{~g} / \mathrm{L}$. Ni-Co/SiC nanocomposites prepared at $10 \mathrm{~g} / \mathrm{L}$ had the finest and most uniform microstructure compared with the others. When SiC concentration increased from 5 to $10 \mathrm{~g} / \mathrm{L}$, average grain size in $\mathrm{Ni}-\mathrm{Co} / \mathrm{SiC}$ nanocomposites decreased from $67.5 \mathrm{~nm}$ to $58.1 \mathrm{~nm}$. AFM revealed that $\mathrm{Ni}-\mathrm{Co} / \mathrm{SiC}$ nanocomposite deposited at $10 \mathrm{~g} / \mathrm{L}$ possessed a fine and uniform microstructure without any evident defects such as pores or cracks. Ni-Co/SiC nanocomposite deposited at $10 \mathrm{~g} / \mathrm{L}$ with average microhardness of $894.5 \mathrm{Hv}$ possessed the minimum corrosion current density of $1.6 \times 10^{-3} \mathrm{~mA} / \mathrm{cm}^{2}$, demonstrating its outstanding corrosion resisting property.

Keywords: $\mathrm{Ni}-\mathrm{Co} / \mathrm{SiC}$ nanocomposite; $\mathrm{SiC}$ concentration; effect; corrosion resisting property

\section{$\underline{\text { FULL TEXT }}$}

(C) 2020 The Authors. Published by ESG (www.electrochemsci.org). This article is an open access article distributed under the terms and conditions of the Creative Commons Attribution license (http://creativecommons.org/licenses/by/4.0/). 